\title{
Flame Protection Technologies for Wood: Developing and Testing for Fire of Timbers with a Flame-retardant Coating Based on the Epoxy-amine Composite Modified by Copper(II) Hexafluorosilicate
}

\author{
Borys Mykhalichko1, Helen Lavrenyuk ${ }^{1 *}$ \\ ${ }^{1}$ Department of Physics and Chemistry of Combustion, L'viv State University of Life Safety, 79007 L'viv, Kleparivs'ka St. $35 .$, \\ Ukraine \\ *Corresponding author, e-mail: lavrenyuk@ldubgd.edu.ua
}

Received: 06 August 2021, Accepted: 19 October 2021, Published online: 24 January 2022

\begin{abstract}
A new type of fire-retardant coating for wood based on epoxy-amine composites modified with copper(II) hexafluorosilicate has been developed. To optimize the composition of the fire-retardant coating, the values of ignition and self-ignition temperatures, the combustibility group indices and the smoke generation coefficient of the developed epoxy-amine composites were used. It was found that the values of the ignition and self-ignition temperatures of epoxy-amine composites containing a flame retardant are higher than those of composites without it, by $15-34^{\circ} \mathrm{C}$ and $25-58^{\circ} \mathrm{C}$, respectively. Compared to unmodified epoxy-amine composites, $\mathrm{CuSiF}_{6}$-modified epoxy-amine composites have $204-327^{\circ} \mathrm{C}$ lower values of the maximum temperature of combustion gases and 7.8-10.4\% less mass loss during combustion. It is shown that modified epoxy-amine composites with an optimized composition are classified as hardly combustible materials with moderate smoke-forming ability. Based on the results of experimental studies, the technological mode of coating the wood was chosen. The developed epoxy-amine composite with reduced combustibility has been used as a fire-retardant coating for wooden structures. Testing for fire showed that developed coating belongs the first group of fire protection efficiency, which ensures reliable fire protection of wood. In contrast, the coatings based on epoxy-amine composites without a flame retardant do not provide fire protection of wood at all.
\end{abstract}

\section{Keywords}

fire protection technology for wood, flame-retardant coatings, testing for fire, smoke-generation tests, flame protection efficiency group

\section{Introduction}

Wood is known to be one of the most widespread and affordable building materials for many centuries. This is due to a number of valuable properties. Wood is easy to process, corrosion-resistant, has high strength, low density and thermal conductivity, etc. [1].

However, high susceptibility to fire, combustibility and other fire hazardous properties often limit the use of wood as a structural material [2]. To eliminate these disadvantages, in particular, to ensure the fire resistance of wood when exposed to low-power ignition sources, to reduce the rate of flame propagation over the surface, fire-retardant coatings are widely used [3-5].

To protect wood from fire, coatings are most often used that can comprehensively prevent the combustion process both in the gas and in the solid phases. The mechanism of wood protection in the gas phase is to prevent the oxidation of the products of thermal decomposition of wood, and in the solid phase - in changing the decomposition process itself.

Among the most promising flame protection means are fire-retardant coatings based on modified polymers [6-9], including epoxy polymers. Such coatings are multi-component systems, the main ingredients of which are a binder, a curing agent and a flame retardant [10]. In world practice, reactive flame retardants are increasingly used, while the use of inert flame retardants is permanently decreasing. The indisputable advantages of reactive flame retardants are the ability to chemically interact with polymers, which is a prerequisite to maintain the proper level of their physicomechanical and physicochemical properties [11]. 
Transition metal salts are a special class of inorganic substances with fire-retardant properties used to modify polymer composites based on epoxy resins [12]. The $d$-metal atoms of such salts have a high electron-acceptor ability as to various donor heteroatoms (N, S, O, etc.) of organic substances, as a result of which strong coordination compounds are formed.

Ordian et al. [13] studied the effect of triethylenetetramine complexes of $\mathrm{Ce}(\mathrm{III}), \mathrm{Co}(\mathrm{II}), \mathrm{Mn}(\mathrm{II}), \mathrm{Ni}(\mathrm{II})$, and $\mathrm{Cr}$ (III) salts on the combustibility of epoxy composites. It was found that the limiting oxygen index (LOI) for these composites depends on both the type of $d$-metal and the nature of the anion. The same authors argue that the fire-retardant effect caused by $d$-metal-amine complexing is primarily due to the presence of mobile hydrogen atoms, exhibiting antioxidant properties. In addition, during the combustion of epoxy composites, oxides of some $d$-metals can form a rather dense film at the polymer-gas interface, thus providing effective flame extinguishing.

The addition of 3(5)-methylpyrazole complexes of inorganic salts of cobalt(II), manganese(II), nickel(II), and zinc(II) as fire retardants in the epoxy-amine composite increases their fire and thermal resistances. It is interesting that the physical and mechanical properties of such epoxy composites remain at the proper level [14].

The regularities of ignition and combustion of epoxy materials containing chromium (II) and nickel (II) acetate as fire retardants were studied in [15]. According to the proposed mechanism, the effect of metal-containing additives is to intensify coking, which leads to better thermal insulation of the polymer decomposing under the coke crust. The decrease in the temperature of the destroyed material is the reason for the decrease in the gasification rate. In this case, less combustible gases can enter the flame and thus slow down the combustion.

Modification of epoxy resins with ammonia, monoethanolamine and diethanolamine complexes of copper(II) cyanurate and copper(II) diallylisocyanurate [16] results in a significant increase in the fire resistance of polymer composites, characterized by LOI. A regularity was found according to which, with an increase in the metal content in the complex, LOI increases to a maximum value and then decreases uniformly. Moreover, epoxy composites modified with diallylisocyanuric acid metal complexes have a lower LOI value, while a higher metal content is required to achieve the maximum LOI value than in the case of epoxy composites modified with cyanuric acid metal complexes.
In recent years, organometallic frameworks have been widely synthesized and used in epoxy composites as an attractive alternative to traditional nanoparticles. Those are well combined and interact with the epoxy matrix without the need for further modification. Due to the content of nitrogen- or phosphorus-containing groups and aromatic substituents, organic binders in the structures of organometallic frameworks support to increase the fire resistance of the epoxy matrix. In addition, thermal destruction of organometallic frameworks is accompanied by the formation of transition metal oxides, which can have a catalytic effect and facilitate to form a carbonized residue in the condensed phase. It is also known that the addition of organometallic components significantly reduces the release of heat, smoke, carbon(IV) and carbon(II) oxides during the combustion of epoxy resins. It is assumed that this effect is the result of oxidation of metallic elements in the structure of organometallic frameworks [17].

The use of polyethylene-polyamine complexes of copper(II) sulfate [18-21] and copper(II) carbonate [22-24] as fire retardant-hardeners of epoxy resins turned out to be extremely effective. It is shown that the thermal stability of $\mathrm{Cu}(\mathrm{II})$-containing epoxy-amine composites increases due to chemical interaction (complexation) of an inorganic copper(II) salt with an organic amine hardener, which is accompanied by the formation of strong $\mathrm{Cu}$ (II)-N bonds. It was also found that modified composites, compared to unmodified ones, are less susceptible to flame and even incapable of igniting from low power ignition sources. Composites containing this type of flame retardant exhibit significantly lower smoke and flame propagation rates compared to composites without the addition of an inorganic copper(II) salt. Due to their unusual ability to form chelate complexes, these copper(II) salts can be incorporated into the polymer framework of the composites, which ensures that the performance characteristics of these epoxy-amine composite materials are supported at the proper level $[25,26]$. These results prompted the search for new fire retardants for epoxy resins $[27,28]$ to obtain epoxy-amine composite materials with a reduced fire hazard [29], which could be used as a fire-retardant coating for wood.

This paper reports the working-out of a unique flame protection technology for wood and testing for fire of timber specimens coated with a flame retardant composite based on epoxy-amine polymers modified with copper(II) hexafluorosilicate. 


\section{Experiments}

\subsection{Materials}

To produce a flame retardant composite the following ingredients have been used: the binder - the epoxy resin brand ED-20 (colorless resin, with about $22 \%$ epoxy groups content, viscosity is $12-18 \mathrm{~Pa} \cdot \mathrm{s}$ at $25{ }^{\circ} \mathrm{C}$ ); the curing agent of epoxy resins - polyethylenepolyamine, pepa $\left(\mathrm{H}_{2} \mathrm{~N}\left[-\mathrm{C}_{2} \mathrm{H}_{4} \mathrm{NH}-\right]_{n} \mathrm{H}\right.$, where $n=1-3$, yellow transparent viscous liquid, containing ethylenediamine (eda), about $90 \%$ of diethylenetriamine (deta), and triethylenetetramine (teta), curing ability as to ED-20 is not less than $\left.60 \mathrm{~min}, d^{20}=1.05 \mathrm{~g} \cdot \mathrm{cm}^{-1}\right)$; and the flame retardant - anhydrous copper(II) hexafluorosilicate, $\mathrm{CuSiF}_{6}$ (noncombustible white powder, $\Delta T_{\text {decomposition }}=174-446^{\circ} \mathrm{C}$ ). To fire test, pine samples in the form of a rectangular block measuring $150 \times 60 \times 30 \mathrm{~mm}^{3}$ have been used.

\subsection{Synthesis of a flame retardant-hardener for epoxy resins and preparation of a flame-retardant coating for wood}

The flame retardant-hardener of epoxy resins in the form of the $[\mathrm{Cu}(e d a)($ deta $)] \mathrm{SiF}_{6}$ chelate complex was obtained according to the method described in detail in [28].

The flame-retardant coating based on epoxy-amine polymers modified with copper(II) hexafluorosilicate can be obtained in two ways. According to the first method, the polymer sample is obtained starting from the flame retardant-hardener and the binder [29]. For this, the $[\mathrm{Cu}(e d a)$ (deta) $\mathrm{SiF}_{6}$ chelate complex is mixed with ED-20. Next, the resulting mixture is stirred until a homogeneous aesthetically attractive dark blue thick mass is formed. The polymer sample prepared in the first method is indicated in Table 1 as $\mathrm{ED} /$ pepa/CuSiF$(\mathrm{II})$.

According to the second method, ED-20 and pepa taken in corresponding ratios were stirred for 5-10 minutes. Then the appropriate amount of anhydrous copper(II) hexafluorosilicate (see Table 1) was added and the resulting mixture was continued to stir until a homogeneous consistency was formed. After the addition of $\mathrm{CuSiF}_{6}$, the curing of the composites was accompanied by a color change from light yellow to dark blue. This indicates the bonding of the inorganic copper(II) salt with pepa to form the $[\mathrm{Cu}(e d a)($ deta $)] \mathrm{SiF}_{6}$ chelate complex.

For comparison, the original composite without a flame retardant was prepared by mixing the appropriate amount of the ED-20 binder with the pepa curing agent.

\subsection{Wood treatment with flame retardant composition}

Before applying the fire retardant, the wood samples were brought to constant weight in a thermostat at $45 \pm 2{ }^{\circ} \mathrm{C}$. The coating was applied with a brush in two layers. The total consumption of the flame retardant composition is $\approx 100-150 \mathrm{~g} \cdot \mathrm{m}^{-2}$. After applying the coating, the wood specimens were kept at room temperature for 24 hours until the coating was completely cured.

\subsection{Test methods}

\subsubsection{Flammability tests}

The temperatures of ignition $\left(T_{\text {ignition }}\right)$ and self-ignition ( $\left.T_{\text {self-ignition }}\right)$ of the flame-retardant coating based on modified epoxy-amine composites were measured on a temperature of flammability (TF) apparatus in accordance with ASTM D1929-16 [30]. For this, ten cylindrical shaped specimens were prepared for each type of test specimen weighing $3 \mathrm{~g}$. Before testing, the specimens were conditioned.

\subsubsection{Combustibility tests}

The combustibility of a fire-retardant coating based on epoxy-amine composites was determined using a ceramic tube (CT) device (Fig. 1) in accordance with GOST 12.1.044-89 [31]. Specimens of wood $150 \mathrm{~mm}$ long, $60 \mathrm{~mm}$ wide and $5 \mathrm{~mm}$ thick were wrapped in a fiberglass cloth. Before testing, the specimens were conditioned and weighed. Then the specimens were placed in a ceramic tube preheated to $200{ }^{\circ} \mathrm{C}$ using a gas burner flame. The maximum temperature of the combustion

Table 1 Stoichiometry of epoxy-amine composites

\begin{tabular}{|c|c|c|c|c|c|c|}
\hline \multirow{2}{*}{ Composite } & \multicolumn{3}{|c|}{ Molar ratio } & \multicolumn{3}{|c|}{ Mass ratio } \\
\hline & ED-20 & рера & $\mathrm{CuSiF}_{6}$ & ED-20 & рера & $\mathrm{CuSiF}_{6}$ \\
\hline $\mathrm{ED} / p e p a$ & 2.5 & 1 & 0 & 100 & 12 & 0 \\
\hline $\mathrm{ED} / p e p a / \mathrm{CuSiF}_{6}(\mathrm{I})$ & 2.5 & 1 & 0.5 & 100 & 12 & 11 \\
\hline $\mathrm{ED} / p e p a / \mathrm{CuSiF}_{6}(\mathrm{II})$ & 2.5 & 1 & 1 & 100 & 12 & 22 \\
\hline 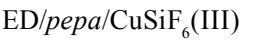 & 2.5 & 1 & 2 & 100 & 12 & 44 \\
\hline $\mathrm{ED} /$ pepa$/ \mathrm{CuSiF}_{6}(\mathrm{IV})$ & 2.5 & 1 & 3 & 100 & 12 & 66 \\
\hline $\mathrm{ED} /$ pepa $/ \mathrm{CuSiF}_{6}(\mathrm{~V})$ & 2.5 & 1 & 4 & 100 & 12 & 88 \\
\hline
\end{tabular}




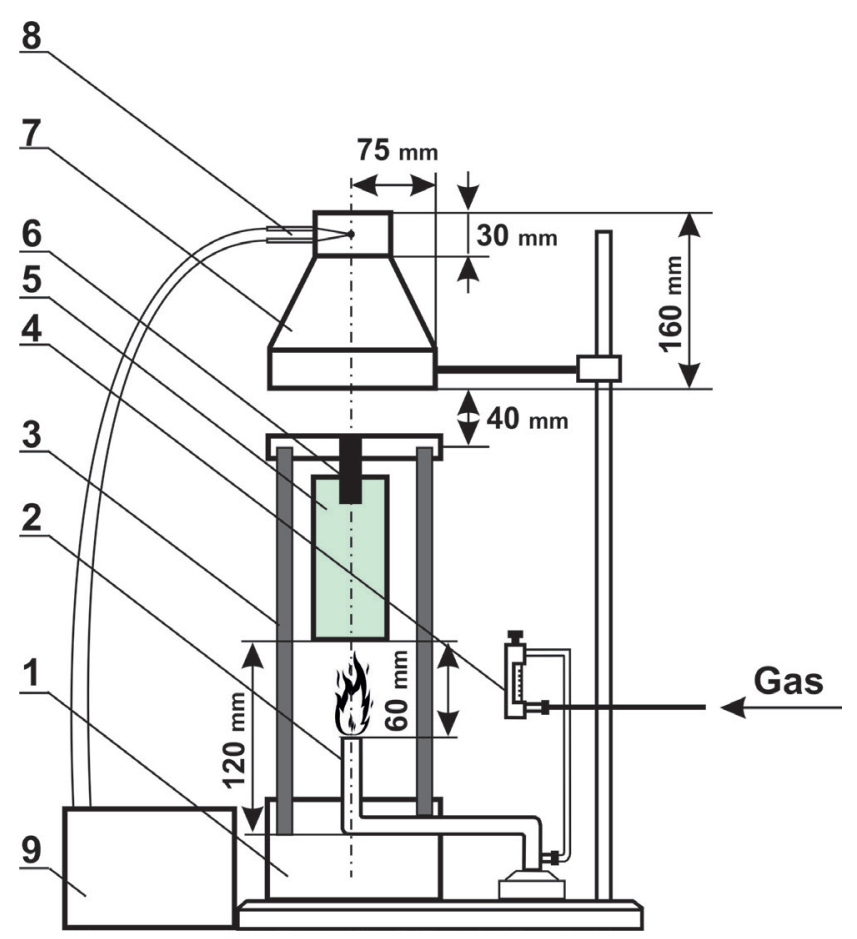

Fig. 1 Schematic of the "ceramic tube" apparatus: 1 - supporting block; 2 - gas burner; 3 - ceramic tube; 4 - gas flowmeter; 5 - test sample; 6 - sample holder; 7 - funnel cover; 8 - thermocouple; 9 - potentiometer

gases $\left(T_{\max },{ }^{\circ} \mathrm{C}\right)$ and the time to reach this maximum temperature $(\Delta \tau, \mathrm{s})$ were measured experimentally. The maximum temperature increment $\left(\Delta T_{\max },{ }^{\circ} \mathrm{C}\right)$ and the relative mass loss $(\Delta m, \%)$ were determined as:

$T_{\max }=T_{\max }-200$,

$m=\frac{m_{b}-m_{a}}{m_{b}} 100 \%$

where $m_{b}$ and $m_{a}$ are mass ( $\mathrm{g}$ ) of a specimen before and after testing, respectively.

The combustibility group of the investigated fire-retardant coating was determined by the $\Delta T_{\max }$ and $\Delta m$ values, and the combustibility of coated wood specimens was determined by the $\Delta \tau$ value.

\subsubsection{Smoke-generation tests}

The smoke production coefficient for fire-retardant coatings based on epoxy-amine composites was measured in a combustion chamber according to ASTM E662-19 [32]. The essence of the method for the experimental determination of the smoke production coefficient is to determine the optical density of smoke, which is formed during the combustion or smoldering of a certain amount of a specimen of solid material. For the study, specimens were prepared in the form of films with a size of $40 \times 40 \mathrm{~mm}^{2}$. Before testing, the prepared specimens were kept at $20^{\circ} \mathrm{C}$ for 48 hours, after which those were weighed.

The specimens were tested in two modes. In the smoldering mode, the specimens are exposed only to a heat flow with a density of $35 \pm 3.5 \mathrm{~kW} \cdot \mathrm{m}^{-2}$, and in the combustion mode, the specimens were simultaneously exposed to the heat flow and the flame of a gas burner.

The smoke production coefficient $\left(D_{\mathrm{m}}, \mathrm{m}^{2} \cdot \mathrm{kg}^{-1}\right)$ was determined by Eq. (3):

$$
D_{m}=\frac{V}{L \times m} \ln \frac{T_{0}}{T_{\min }},
$$

where $V, \mathrm{~m}^{3}$ is the volume of the chamber $(V=$ $\left.0.343 \pm 0.004 \mathrm{~m}^{3}\right) ; L, \mathrm{~m}$ is path length of a light beam in a smoke-filled environment $(L=0.700 \pm 0.0005 \mathrm{~m}) ; \mathrm{m}, \mathrm{kg}$ is the mass of the specimen; $T_{0}, \%$ is the value of the initial light transmission; $T_{\min }, \%$ is the value of the final light transmission.

According to the $D_{\mathrm{m}}$ value, the materials were assigned to the following group:

- with low smoke-generating ability $\left(D_{\mathrm{m}} \leq 50 \mathrm{~m}^{2} \cdot \mathrm{kg}^{-1}\right)$;

- with moderate smoke-generating ability $\left(50<D_{\mathrm{m}} \leq\right.$ $\left.500 \mathrm{~m}^{2} \cdot \mathrm{kg}^{-1}\right)$;

- with high smoke-generating ability $\left(D_{\mathrm{m}}>500 \mathrm{~m}^{2} \cdot \mathrm{kg}^{-1}\right)$.

\subsubsection{Thermogravimetric analysis}

Thermogravimetric analysis of $\mathrm{ED} / p e p a$ and $\mathrm{ED} / p e p a /$ $\mathrm{CuSiF}_{6}$ (II) specimens was carried out on a Q-1500D thermal analyzer (F. Paulik, J. Paulik, L. Erdey system) in the temperature range from $25{ }^{\circ} \mathrm{C}$ to $1000{ }^{\circ} \mathrm{C}$ with a heating rate of $5{ }^{\circ} \mathrm{C}$ per minute. All measurements were carried out dynamically in air. The weight of each specimen was $100 \mathrm{mg}$. Aluminum oxide was used as a standard.

\subsubsection{Evaluation of fire-retardant efficiency of coatings for wood}

The assessment of the fire-retardant efficiency of the coatings was carried out in accordance with GOST 1636398 [33]. The essence of the method is to determine the mass loss of wood coated with a flame retardant, which is exposed to a flame in conditions conducive to heat accumulation.

Before testing, the specimens were weighed and placed into a CT device (see Fig. 1). After bringing in the burner inside the ceramic tube and reaching a temperature of $200 \pm 5^{\circ} \mathrm{C}$, the specimens were kept in the burner flame for 2 minutes. After cooling, the specimens were reweighed. 
The index of fire-retardant efficiency of coatings for wood $(P, \%)$ was determined with an accuracy of $0.1 \%$ by Eq. (4):

$$
P=\frac{m_{1}-m_{2}}{m_{1}} 100 \%,
$$

where $m_{1}, \mathrm{~g}$ is the mass of the sample before test; $m_{2}, \mathrm{~g}$ is the mass of the sample after the test.

According to the test results, the flame protection efficiency (FPE) group was ascertained:

- I group $(P \leq 9 \%)$;

- II group $(9<P \leq 25 \%)$;

- coating does not provide the fire protection of wood $(P>25 \%)$.

\section{Results and discussion}

\subsection{Optimization of the flame-retardant coating composition}

The nature of the flame retardant used for the manufacture of epoxy composite materials is one of the most important characteristics that should be taken into account when choosing the optimal composition and technological regime to coat a wooden surface. Usually, the control of the quantitative ratio of ingredients in composites and the improvement of heat treatment modes make it possible to obtain materials with desired properties.

Analysis of the results obtained to study the effect of copper(II) hexafluorosilicate on the fire hazard parameters of epoxy-amine composites confirms the high efficiency of $\mathrm{CuSiF}_{6}$ use as a flame retardant of the reactivity type. A comparative assessment of fire hazard parameters of original and modified epoxy-amine composites shows that those significantly depend on the composition of the epoxy-polymer material, or rather, on the quantitative content of incombustible inorganic copper(II) salt. The dependences of temperatures of ignition and self-ignition on the content of flame retardant in epoxy-composites are presented in Fig. 2. One can see, when adding flame retardant, the ignition and self-ignition temperatures of the composites increase by $15-34{ }^{\circ} \mathrm{C}$ and $25-58{ }^{\circ} \mathrm{C}$, respectively. The maximum values of temperatures of ignition $\left(359{ }^{\circ} \mathrm{C}\right)$ and self-ignition $\left(588{ }^{\circ} \mathrm{C}\right)$ were recorded for epoxy-amine composites containing 88 mass parts of $\mathrm{CuSiF}_{6}$ per 100 mass parts of ED-20.

The rate of combustible decomposition products formation, their diffusion into the environment and the rate of their oxidation are known to be determined the ability of polymer materials to ignite and self-ignite. Reducing the rate of

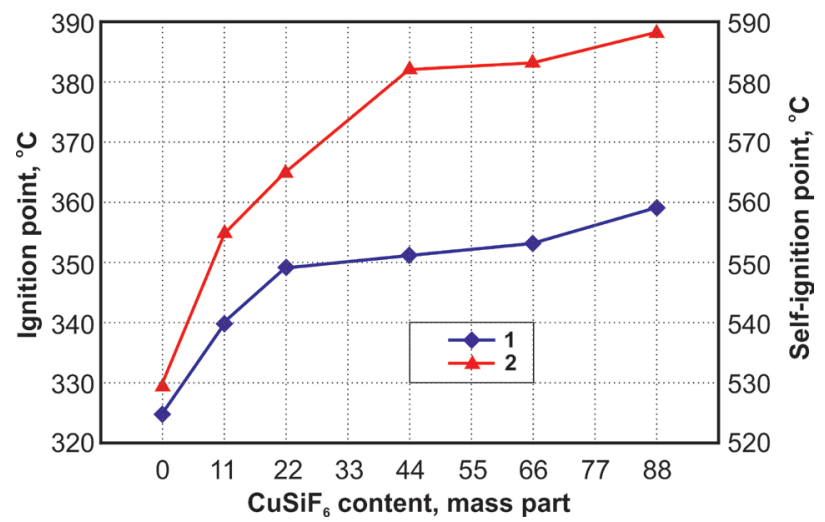

Fig. 2 The dependences of ignition point (curve 1) and self-ignition point (curve 2) on the content of $\mathrm{CuSiF}_{6}$ in epoxy-amine composites

combustible decomposition products formation increases the ignition and self-ignition temperatures of materials.

When an incombustible inorganic salt $\left(\mathrm{CuSiF}_{6}\right)$ is used as a flame retardant additive for epoxy-amine composites, a strong chelate complex $[\mathrm{Cu}($ eda $)($ deta $)] \mathrm{SiF}_{6}$ is formed inside the polymer framework. In this complex, copper(II) hexafluorosilicate chemically bonds the combustible curing agent (pepa). To break the $\mathrm{Cu}(\mathrm{II})-\mathrm{N}$ bonds formed in this process, additional energy is required. This influences on the rate of decomposition of epoxy-amine composites and explains the reasons for the increase in the ignition and self-ignition temperatures. Here, the ratio of thermal destruction products changes towards the formation of a larger amount of non-combustible gases. After all, copper(II) hexafluorosilicate contained in epoxy-amine composites is able to decompose with the release of incombustible copper(II) fluoride and silicon(IV) fluoride.

The additions of copper(II) hexafluorosilicate to epoxyamine composites have a positive effect on their combustibility indices (Fig. 3). As can be seen, the composite that does not contain a flame retardant (ED/pepa) has the highest value of the maximum temperature of the gaseous combustion products $\left(T_{\max }=867\right)$, as well as the greatest mass loss during combustion $(\Delta m=89.0 \%)$. Therefore, this composite belongs to combustible materials. The $\mathrm{ED} /$ pepa $/ \mathrm{CuSiF}_{6}(\mathrm{I})$, $\mathrm{ED} /$ pepa $/ \mathrm{CuSiF}_{6}(\mathrm{II})$, and $\mathrm{ED} /$ pepa/ $\mathrm{CuSiF}_{6}(\mathrm{III})$ composites in which the flame retardant content is 11, 22 and 44 mass parts of $\mathrm{CuSuF}_{6}$, respectively, can also be attributed to combustible materials, but their combustibility indices are significantly reduced. However, the addition of 66 , and 88 mass parts of $\mathrm{CuSiF}_{6}$ to the composite significantly increases their combustibility indices. Since the maximum temperature increment for the $\mathrm{ED} /$ pepa/ $\mathrm{CuSiF}_{6}(\mathrm{IV})$ and $\mathrm{ED} /$ pepal $\mathrm{CuSiF}_{6}(\mathrm{~V})$ specimens does not exceed $60{ }^{\circ} \mathrm{C}$, and the mass 


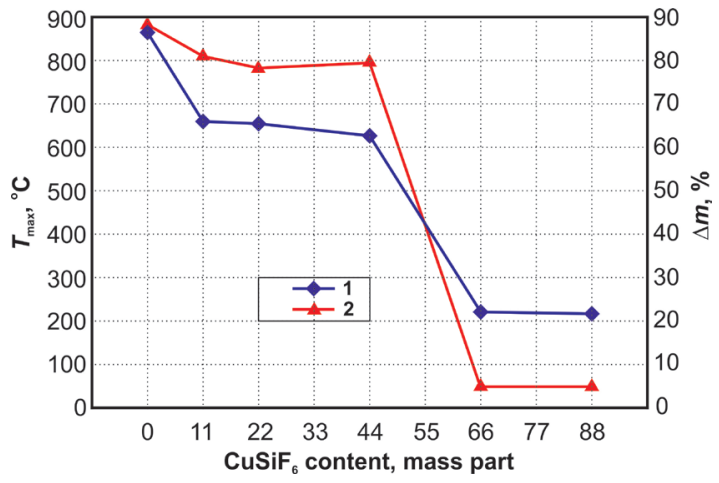

Fig. 3 The dependences of the maximum temperature of gaseous combustion products, $T_{\max }$ (curve 1) and the mass loss during combustion, $\Delta m$ (curve 2 ) on the content of $\mathrm{CuSiF}_{6}$ in epoxy-amine composites

loss during combustion is less than $60 \%$, these composites are classified as hardly combustible materials.

A visual assessment of the features of the combustion process gives grounds to claim that the ED/pepa specimens burn very easily and quickly with the production of an extremely large amount of smoke and soot, and their combustion is difficult to extinguish. The ED/pepal $\mathrm{CuSiF}_{6}(\mathrm{I}), \mathrm{ED} /$ pepa $/ \mathrm{CuSiF}_{6}$ (II) and $\mathrm{ED} /$ pepa/CuSiF$($ III) specimens are more resistant to combustion, and the ED/ pepa/CuSiF 6 (IV) and $\mathrm{ED} /$ pepa/CuSiF 6 (V) specimens burn only when exposed to the burner flame, but when the flame is removed, these specimens stop burning immediately.

The smoke-generating ability of epoxy-amine composites was evaluated from the determination results of the smoke production coefficient in burning and smoldering modes. The data obtained are shown in Fig. 4. It was found that the $\mathrm{ED} /$ pepa/ $\mathrm{CuSiF}_{6}$ (III) composite, containing 44 mass parts of $\mathrm{CuSiF}_{6}$, has the least value of the smoke production coefficient in the smoldering



Fig. 4 The dependences of the smoke production coefficient $\left(D_{\mathrm{m}}\right)$ in the smoldering mode (curve 1) and the burning mode (curve 2) on the content of $\mathrm{CuSiF}_{6}$ in epoxy-amine composite mode $\left(D_{\mathrm{m}}=497.42 \mathrm{~m}^{2} \cdot \mathrm{kg}^{-1}\right)$ and belongs to materials with moderate smoke-generating ability. For the rest of the composites, the $D_{\mathrm{m}}$ values determined in the same mode exceed $500 \mathrm{~m}^{2} \cdot \mathrm{kg}^{-1}$; therefore, those are classified as materials with high smoke-generating ability.

A slightly different behavior of composite materials is observed when determining the smoke production coefficient in the burning mode. The addition of the fire retardant in an amount of 44 mass parts and large transfers these composites from the group of materials with high smoke-generating ability to the group of materials with moderate smoke-generating ability. The smoke production coefficient for the $\mathrm{ED} /$ pepa/ $\mathrm{CuSiF}_{6}(\mathrm{~V})$ composite containing 88 mass parts of the flame retardant is approximately half that of the original ED/pepa composite.

Thus, the dependence of all of the above indices of the fire hazard of epoxy-amine composites on the content of the flame retardant is nonlinear. This made it possible to find the optimal range of flame retardant concentrations (from 22 to 66 mass parts of $\mathrm{CuSiF}_{6}$ per 100 mass parts of ED-20), at which the $\mathrm{ED} /$ pepa/CuSiF$_{6}(\mathrm{II}), \mathrm{ED} /$ pepa/ $\mathrm{CuSiF}_{6}$ (III) and $\mathrm{ED} /$ pepa/ $\mathrm{CuSiF}_{6}$ (IV) composites are characterized by increased fire safety. Outside the upper limit of the optimal fire retardant concentration range, the composites will have the highest values of temperatures of ignition $\left(T_{\text {ignition }}\right)$ and self-ignition $\left(T_{\text {self-ignition }}\right)$, the lowest value of the maximum temperature of gaseous combustion products $\left(T_{\max }\right)$ and the mass loss during combustion $(\Delta m)$. Although an increase in the fire retardant content has a positive effect on the fire hazard indices of the resulting epoxy-amine composites, the excessive addition of $\mathrm{CuSiF}_{6}$ is still technologically unjustified, since the viscosity of the composite increases significantly. This negatively affects the preparation time of the flame-retardant coating, as well as the quality of the finished product.

For the application of flame-retardant coatings on wood, the developed epoxy-amine composites modified with copper(II) hexafluorosilicate of the following optimized composition (wt.\%) have been used:

- the epoxy resin (ED-20): -56.2-74.6;

- the curing agent of epoxy resins (pepa): -6.7-9.0;

- the flame retardant $\left(\mathrm{CuSiF}_{6}\right):-16.4-37.1$.

\subsection{Efficiency determination of flame-retardant coatings for wood}

One of the criteria determining the protective potential of an epoxy coating when applied to wood is the degree of curing $[34,35]$. The results of thermogravimetric 
measurements show that unmodified (ED/pepa) and modified $\left(\mathrm{ED} /\right.$ pepa $\left./ \mathrm{CuSiF}_{6}\right)$ composites are characterized by high thermal stability up to $250^{\circ} \mathrm{C}$. However, the temperature of the initial stage of intensive weight loss of the modified composite is shifted towards higher temperatures by $13{ }^{\circ} \mathrm{C}[36]$. It is assumed that the retardation of the destruction of the epoxy composite upon the addition of the flame retardant is a consequence of the $\mathrm{CuSiF}_{6}$-(pepa) chelation.

To determine the effectiveness of the fire-retardant coating, pine specimens coated with an epoxy-amine composite without a flame retardant and a composite modified with copper(II) hexafluorosilicate, as well as a specimen of uncoated wood, were tested (Fig. 5). Fig. 6 shows the same specimens after combustibility tests.

Fire tests showed (Table 2) that the weight loss of wood coated with $\mathrm{CuSiF}_{6}$-modified epoxy-amine composite was only $7.2 \%$. This specimen can only burn when exposed to an open flame and stops burning immediately after the flame is removed (see Fig. 6c). This makes it possible to classify the developed coating to the I group of the flame
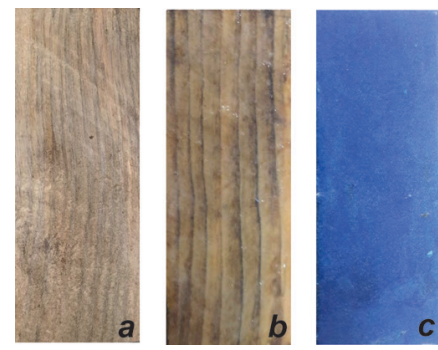

Fig. 5 Wood specimens $\left(150 \times 60 \times 30 \mathrm{~mm}^{3}\right): a-$ with no coating; $b$ - coated with epoxyamine composite; $c$ - coated with $\mathrm{CuSiF}_{6}$-modified epoxy-amine composite
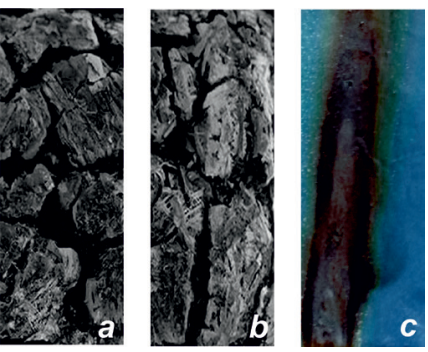

Fig. 6 Wood specimens $\left(150 \times 60 \times 30 \mathrm{~mm}^{3}\right)$ after the combustibility tests: $a-$ with no coating; $b$-coated with epoxyamine composite; $c$ - coated with $\mathrm{CuSiF}_{6}$-modified epoxy-amine composite
Table 2 The flame protection efficiency of coatings applied to the wood surface [33]

\begin{tabular}{lcc}
\hline Samples & $P, \%$ & FPE group \\
\hline Uncoated wood & 87.7 & - \\
$\begin{array}{l}\text { Wood coated with epoxy-amine composite } \\
\text { with no flame retardant }\end{array}$ & 83.5 & $*$ \\
$\begin{array}{l}\text { Wood coated with epoxy-amine composite } \\
\text { containing a flame retardant }\end{array}$ & 7.2 & I \\
\hline
\end{tabular}

* The coating does not provide the flame protection of wood

protection efficiency. This coating renders wood a fire-resistant material. A coating based on an epoxy-amine composite without a flame retardant does not provide fire resistance of wood at all (Fig. $6 b$ ), since the mass loss of the specimen is significantly greater than $25 \%$ and amounts to $83.5 \%$. However, the greatest mass loss $(87.7 \%)$ is observed for the uncoated wood specimen (Fig. 6a).

Therefore, the data obtained indicates the high efficiency of the use of epoxy-amine composites modified with copper(II) hexafluorosilicate for a fire-retardant coating of wood.

\section{Conclusion}

Studies have shown that controlled modification of epoxyamine composites with copper(II) hexafluorosilicate provides a significant reduction in the combustibility of the developed polymer materials. This behavior of the composites is due to the effective chelation of combustible molecules of the hardener (ethylenediamine and diethylenetriamine) with a non-combustible inorganic salt $\mathrm{CuSiF}_{6}$ (flame retardant), which occurs during the curing of epoxy-amine composites. In particular, when adding the flame retardant to an epoxy-amine composite, the ignition and self-ignition temperatures of the modified composites increase by $15-34{ }^{\circ} \mathrm{C}$ and $25-58{ }^{\circ} \mathrm{C}$, respectively. In addition, the composite that does not contain a flame retardant (ED/pepa) has the highest value of the maximum temperature of the gaseous combustion products $\left(T_{\max }=867^{\circ} \mathrm{C}\right)$, as well as the greatest mass loss during combustion $(\Delta m=89.0 \%)$. However, the addition of 66 mass parts of $\mathrm{CuSiF}_{6}$ to the composite reduces $T_{\max }$ and $\Delta m$ to $220{ }^{\circ} \mathrm{C}$ and $4.9 \%$, respectively. These data served as the basis for the transfer of these polymer samples from the category of combustible materials with moderate flammability to the category of hardly combustible materials. The addition of the flame retardant to epoxy-amine composites also reduces smoke generation during combustion and smoldering of specimens, which ensures the production of polymer materials with moderate smoke-generating ability. The 
optimal concentration of the flame retardant should be in the range from 22 to 66 mass parts of $\mathrm{CuSiF}_{6}$ per 100 mass parts of the binder, while the resulting composites will be characterized by increased fire safety. It was found that a fire-retardant coating for wooden structures based on

\section{References}

[1] Nikolic, M., Lawther, J. M., Sanadi, A. R. "Use of nanofillers in wood coatings: a scientific review", Journal of Coatings Technology and Research, 12(3), pp. 445-461, 2015. https://doi.org/10.1007/s11998-015-9659-2

[2] Ira, J., Hasalová, L., Šálek, V., Jahoda, M., Vystrčil, V. "Thermal Analysis and Cone Calorimeter Study of Engineered Wood with an Emphasis on Fire Modelling", Fire Technology, 56(3), pp. 1099-1132, 2020.

https://doi.org/10.1007/s10694-019-00922-9

[3] Chen, X., Li, J., Gao, M., Yue, L., Zhou, X. "Fire protection properties of wood in waterborne epoxy coatings containing functionalized graphene oxide", Journal of Wood Chemistry and Technology, 39(5), pp. 313-328, 2019.

https://doi.org/10.1080/02773813.2019.1601740

[4] Xiao, Z., Liu, S., Zhang, Z., Mai, C., Xie, Y., Wang, Q. "Fire retardancy of an aqueous, intumescent, and translucent wood varnish based on guanylurea phosphate and melamine-urea-formaldehyde resin", Progress in Organic Coatings, 121, pp. 64-72, 2018.

https://doi.org/10.1016/j.porgcoat.2018.04.015

[5] Guo, C., Yi, T., Morrell, J. J., Gao, W., Zhao, S., Zhan, K., Yang, L., $\mathrm{Du}, \mathrm{G}$. "Incorporation of a nano/micro $\mathrm{CuO}$ formulation into phenol formaldehyde (PF) resin: Curing kinetics, morphological analysis, and application", Journal of Wood Chemistry and Technology, 39(5), pp. 372-383, 2019.

https://doi.org/10.1080/02773813.2019.1636822

[6] Li, Y.-C., Yang, Y.-H., Shields, J. R., Davis, R. D. "Layered double hydroxide-based fire resistant coatings for flexible polyurethane foam", Polymer, 56, pp. 284-292, 2015.

https://doi.org/10.1016/j.polymer.2014.11.023

[7] Hidalgo, J. P., Torero, J. L., Welch, S. "Fire performance of charring closed-cell polymeric insulation materials: Polyisocyanurate and phenolic foam", Fire and Materials, 42(4), pp. 358-373, 2018. https://doi.org/10.1002/fam.2501

[8] Hidalgo, J. P., Torero, J. L., Welch, S. "Experimental Characterization of the Fire Behavior of Thermal Iinsulation Materials for a Performance-based Design Methodology", Fire Technology, 53(3), pp. 1201-1232, 2017. https://doi.org/10.1007/s10694-016-0625-Z

[9] Asimakopoulou, E., Zhang, J., Mckee, M., Wieczorek, K., Krawczyk, A., Andolfo, M., ..., Papakonstantinou, P. "Fire Retardant Action of Layered Double Hydroxides and Zirconium Phosphate Nanocomposites Fillers in Polyisocyanurate Foams", Fire Technology, 56(4), pp. 1755-1776, 2020. https://doi.org/10.1007/s10694-020-00953-7

[10] Movahedifar, E., Vahabi, H., Saeb, M. R., Thomas, S. "Flame Retardant Epoxy Composites on the Road of Innovation: An Analysis with Flame Retardancy Index for Future Development", Molecules, 24(21), pp. 3964-4011, 2019. https://doi.org/10.3390/molecules24213964 the obtained epoxy-amine composites has the first group of fire-retardant efficiency, which ensures reliable flame protection of wood. In contrast, coatings based on epoxyamine composites without a flame retardant do not ensure any flame protection to wood at all.

[11] Rad, E. R., Vahabi, H., de Anda, A. R., Saeb, M. R., Thomas, S. "Bio-epoxy resins with inherent flame retardancy", Progress in Organic Coatings, 135, pp. 608-612, 2019. https://doi.org/10.1016/j.porgcoat.2019.05.046

[12] Hamerton, I., Howlin, B., Jepson, P. "Metals and coordination compounds as modifiers for epoxy resins", Coordination Chemistry Reviews, 224(1-2), pp. 67-85, 2002. https://doi.org/10.1016/S0010-8545(01)00393-9

[13] Ordian, M. B., Rashidian, L. G., Ayvazian, G. B., Akopian, A. A., Ogandjanian, A. G., Avanesian, N. A. "Modification of epoxy resin ED-20, cured by mixtures of aromatic diamines, complexes of salts of certain metals with triethylenetetramine", Chemical Journal of Armenia, 31, pp. 763-767, 1978.

[14] Darbinian, E. G., Matsoian, M. S., Sahakian, A. A., Elizian, M. A. "Fire resistant epoxy compositions", Chemical Journal of Armenia, 36, pp. 268-269, 1983.

[15] Ayvazian, G. B., Khalturinsrii, N. A., Akopian, A. A., Rashidian, L. G. "Combustibility of metal-containing epoxy-materials", Chemical Journal of Armenia, 36(5), pp. 332-335, 1983.

[16] Yesaian, G. T., Kazarian, S. M., Ordian, M. B. "Copper-ammonia (amine) salts of cyanuric and diallylisocyanuric acids as flame retardants", Chemical Journal of Armenia, 33, pp. 290-294, 1980.

[17] Seidi, F., Jouyandeh, M., Taghizadeh, M., Taghizadeh, A., Vahabi, H., Habibzadeh, S., Formela, K., Saeb, M. R. "MetalOrganic Framework (MOF)/Epoxy Coatings: A Review", Materials, 13(12), pp. 2881-2897, 2020. https://doi.org/10.3390/ma13122881

[18] Lavrenyuk, H., Mykhalichko, O., Zarychta, B., Olijnyk, V., Mykhalichko, B. "A new copper(II) chelate complex with tridentate ligand: Synthesis, crystal and molecular electronic structure of aqua-(diethylenetriamine-N, $\left.\mathrm{N}^{\prime}, \mathrm{N}^{\prime \prime}\right)$-copper(II) sulfate monohydrate and its fire retardant properties", Journal of Molecular Structure, 1095, pp. 34-41, 2015.

https://doi.org/10.1016/j.molstruc.2015.03.039

[19] Lavrenyuk, O. I., Mykhalichko, B. M. "X-ray powder diffraction and infra-red spectroscopic analysis of the structuring process of modified epoxy-amine composites with the participation of flame retardant $\left[\mathrm{Cu}\right.$ (diethylenetriamine) $\left.\mathrm{H}_{2} \mathrm{O}\right] \mathrm{SO}_{4} \cdot \mathrm{DH}_{2} \mathrm{O}$ ", Voprosy Khimii i Khimicheskoi Tekhnologii, 2016(5-6), pp. 73-77, 2016.

[20] Lavrenyuk, H., Kochubei, V., Mykhalichko, O., Mykhalichko, B. "A new flame retardant on the basis of diethylenetriamine copper(II) sulfate complex for combustibility suppressing of epoxyamine composites", Fire Safety Journal, 80, pp. 30-37, 2016. https://doi.org/10.1016/j.firesaf.2016.01.001

[21] Lavrenyuk, H., Mykhalichko, B. "DFT study on thermochemistry of the combustion of self-extinguishing epoxy-amine composites modified by copper(II) sulfate", Voprosy Khimii I Khimicheskoi Tekhnologii, 2018(6), pp. 42-48, 2018. https://doi.org/10.32434/0321-4095-2018-121-6-42-48 
[22] Lavrenyuk, H., Mykhalichko, O., Zarychta, B., Olijnyk, V., Mykhalichko, B. "Synthesis, structural, and thermal characterization of a new binuclear copper(II) chelate complex bearing an amine-hardener for epoxy resins", Joural of Coordination Chemistry., 69(18), pp. 2666-2676, 2016. https://doi.org/10.1080/00958972.2016.1212340

[23] Lavrenyuk, H., Kochubei, V., Mykhalichko, O., Mykhalichko, B. "Metal-coordinated epoxy polymers with suppressed combustibility. Preparation technology, thermal degradation, and combustibility test of new epoxy-amine polymers containing the curing agent with chelated copper(II) carbonate", Fire and Materials, 42(3), pp. 266-277, 2018. https://doi.org/10.1002/fam.2489

[24] Lavrenyuk, H., Mykhalichko, B. "Principles of controlled effects of performance properties of self-extinguishing epoxy-amine composites modified by copper(II) carbonate", Voprosy Khimii I Khimicheskoi Tekhnologii., 2019(5), pp. 58-64, 2019. https://doi.org/10.32434/0321-4095-2019-126-5-58-64

[25] Lavrenyuk, H., Hamerton, I., Mykhalichko, B. "Tuning the properties for the self-extinguishing epoxy-amine composites containing copper-coordinated curing agent: Flame tests and physical-mechanical measurements", Reacting and Functional Polymers, 129, pp. $95-102,2018$.

https://doi.org/10.1016/j.reactfunctpolym.2017.10.013

[26] Lavrenyuk, H., Parhomenko, V. P., Mykhalichko, B. "The Effect of Preparation Technology and the Complexing on the Service Properties of Self-extinguishing Copper(II) Coordinated Epoxyamine Composites for Pouring Polymer Floors", International Journal of Technology, 10(2), pp. 290-299, 2019. https://doi.org/10.14716/ijtech.v10i2.66

[27] Lavrenyuk, H. I., Mykhalichko, B. M., Parhomenko, V. P. O. "Квантово-химическое моделирование поведения хелатного комплекса $\quad[\mathrm{Cu}(\mathrm{H} 2 \mathrm{NC} 2 \mathrm{H} 4 \mathrm{NH} 2)(\mathrm{H} 2 \mathrm{NC} 2 \mathrm{H} 4 \mathrm{NHC} 2 \mathrm{H} 4 \mathrm{NH} 2)]$ $\mathrm{SiF6,} \mathrm{антипирена-упрочнителя} \mathrm{эпоксидных} \mathrm{смол,} \mathrm{в} \mathrm{условиях}$ горения" (Quantum-chemical simulation of the behavior of $\left[\mathrm{Cu}\left(\mathrm{H}_{2} \mathrm{NC}_{2} \mathrm{H}_{4} \mathrm{NH}_{2}\right)\left(\mathrm{H}_{2} \mathrm{NC}_{2} \mathrm{H}_{4} \mathrm{NHC}_{2} \mathrm{H}_{4} \mathrm{NH}_{2}\right)\right] \mathrm{SiF}_{6}$ chelate complex, a fire retardant-hardener of epoxy resins, under the conditions of burning), Voprosy Khimii I Khimicheskoi Tekhnologii., 3, pp. 31-36, 2018. (in Ukrainian)

[28] Lavrenyuk, H., Mykhalichko, B., Dziuk, B., Olijnyk, V., Mykhalichko, O. "A new copper(II) chelate complex with polyamines as fire retardant and epoxy hardener: Synthesis, crystal and electronic structure, and thermal behavior of (ethylenediamine-N, $\mathrm{N}^{\prime}$ )-(diethylenetriamine-N, $\left.\mathrm{N}^{\prime}, \mathrm{N}^{\prime \prime}\right)$-copper(II) hexafluorosilicate", Arabian Journal of Chemistry, 13(1), pp. 3060-3069, 2020. https://doi.org/10.1016/j.arabjc.2018.08.014
[29] Lavrenyuk, H., Mykhalichko, B., Garanyuk, P., Mykhalichko, O. "New copper(II)-coordinated epoxy-amine polymers with flame-self-extinguishment properties: Elaboration, combustibility testing, and flame propagation rate measuring", Fire and Materials, 44(6), pp. 825-834, 2020.

https://doi.org/10.1002/fam.2879

[30] ASTM International "ASTM D1929-16 Test method for determining ignition temperature of plastics", ASTM International, West Conshohocken, PA, USA, 2016. https://doi.org/10.1520/d1929-20

[31] USSR Ministry of Internal Affairs "GOST 12.1.044-89 Occupational safety standards system. fire and explosion hazard of substances and materials. nomenclature of indices and methods of their determination", USSR Ministry of Internal Affairs, Moscow, Russia, 1989.

[32] ASTM International "ASTME662-19 Standard Test Method for Specific Optical Density of Smoke Generated by Solid Materials", ASTM International, West Conshohocken, PA, USA, 2019.

[33] Interstate Technical Committee "GOST 16363-98 Fire protective means for wood. Methods for determination of fire protective properties", The State Committee of the Russian Federation for Standardization, Metrology and Certification,, Moscow, Russia, 1998.

[34] Jouyandeh, M., Jazani, O. M., Navarchian, A. H., Shabanian, M. Vahabi, H., Saeb, M. R. "Bushy-surface hybrid nanoparticles for developing epoxy superadhesives", Applied Surface Science, 479, pp. 1148-1160, 2019.

https://doi.org/10.1016/j.apsusc.2019.01.283

[35] Jouyandeh, M., Tikhani, F., Hampp, N., Yazdi, D. A., Zarrintaj, P., Ganjali, M. R., Saeb, M. R. "Highly curable self-healing vitrimer-like cellulose-modified halloysite nanotube/epoxy nanocomposite coatings", Chemical Engineering Journal, 396, Article number: 125196,2020 https://doi.org/10.1016/j.cej.2020.125196

[36] Lavrenyuk, H., Kochubei, V., Mykhalichko, O., Mykhalichko, B. "Development and thermal behavior of a new type of polymer materials with reduced combustibility based on epoxy-amine composites modified with copper(II) hexafluorosilicate", Journal of Thermal Analysis and Calorimetry, 2021. https://doi.org/10.1007/s10973-021-10622-8 